\title{
Eulàlia Abad
}

Pedagoga i cantant, ha rebut diversos cursos de formació musical solfeig i 3 anys de piano.

Formació pedagogia Willems, musicoteràpia a la Universitat de Vitòria amb Patxi del Campo, expressió corporal i dansa lliure entre d'altres. Ha participat durant anys en anuncis publicitaris per TV i ràdio, com a cantant solista en anuncis coneguts com Martini, Blevit, Castellblanch, la Once, Mc. Donalds, entre molts d'altres. També com a cantant solista acompanyada per músics com Conrad Setò o Toni Xuclà. en diferents concerts i espectacles. Ha compaginat la pedagogia treballant en diferents escoles bressol i de música de Barcelona, amb nens fins a 5 anys, utilitzant mètodes prestigiosos como els de Martenot i Willems. Durant els últims 20 anys s'ha dedicat a la recerca, desenvolupant el seu propi mètode d'educació musical: Música per Créixer.

Música per Créixer, especial per nens de 0 a 3 i complementari $d^{\prime}$ altres mètodes de 3 a 5 anys He donat formació d'aquesta metodologia en diverses escoles, centres i col-lectius de Catalunya i València, i al Conservatori i escola de música El Musical de Bellaterra durant 15 anys, tenint diferents tipus d'un nombrós alumnat, com llevadores, mestres, musicoterapeutes, músics, cantants, educadors/es en lleure... 


\section{E) EULÀLIA A Jaume I University (Spain)}

\section{Ana M. Vernia}

Eulàlia Abad és un referent en educació musical per a nens i docents. Quan i per què va arribar a la Música?

\section{Eulàlia Abad}

La música sempre era dins meu des de que vaig néixer $O$ abans per què la meva mare li agradava molt cantar i teníem un piano a casa el meu germà $l^{\prime}$ estudiava i em vaig iniciar amb el solfeig. Vaig treballar com a pedagoga i mestre de francès $i$ cantava també,en català en francès i alguna cançó amb anglès. Vaig actuar en diferents llocs com la Cova del drac de Barcelona, acompanyada per diferents pianistes, i guitarristes, també fent anuncis de publicitat, els famosos Martini, Blevit papillas, Quanto, acompanyada pel mestre Verdagí, que alguna vegada amb la seva guitarra també havia tocat en algun anunci. En aquell temps, tota la publicitat era musical. Però a mi m'atreien molt els nens petits, la pedagogia infantil, i la musicoteràpia, i és quan vaig començar a descobrir la meva passió i em vaig iniciar en aquest camp.
AV: Quan parlem de metodologies actives, ens remuntem a finals del segle XIX, principis del XX. Tret del seu mètode, en la seua opinió, per què no eixen més metodologies didàctiques vers la música?

EA: Perquè la gent no estava preparada, tothom creia que els infants tant petits no podien fer res més que escoltar i començar a cantar cançons de bressol tradicionals i poca cosa més, i ningú donava importància a l'educació musical ni a l'educació global a aquestes edats, tampoc els músics professionals. Fins i tot actualment encara hi ha persones i també músics que pensen que qualsevol persona pot donar aquest formació perquè son quatre cançons i quatre exercicis de ritme. Crec que ara hi ha molts mètodes i ha començat a canviar la manera de pensar de molta gent.

\section{AV: El mètode "música per créixer" creat per vostè. Quin és el seu fonament?}

EA: El seu fonament és musical i global, pensant amb les paraules de Willems que ens explicava el paral·lelisme que hi ha entre la música i el ésser humà.

la part física es igual al moviment, la part emo- 
cional és igual a la melodia, i la part mental i espiritual igual a l'harmonia. Per ser complet ha de tenir aquestes tres parts, i la música igual.

Vinculem també els valors, que son les virtuts que tenim dins nostre, les despertem, i amb alegria ho podem transmetre a través del cant, de l'audició, del moviment, de la relaxació.

AV: Sota el seu punt de vista, què ens aporta la música, a les persones, tret dels coneixements purament musicals?

EA: Ens aporta força, alegria, afecte, constància, expressió, comunicació, relaxació, ens ajuda molt a nivell emocional i alhora també ens ajuda a nivell cerebral, la memòria, no acabaria mai...

AV: Amb la seua llarga i important experiència, podria explicar-nos algun cas on la música ha transformat la vida d'algun nen o adult?

EA: Podria explicar molts casos, és molt important pels prematurs, però en adults el de una mestre no fa massa temps que tenia depressió i em va dir que després de les sessions de Música per Créixer ho veia tot diferent, amb una nova perspectiva, i que li havia transmès molta força i ganes de viure. Em vaig emocionar molt. Crec que va ser com un tornar a la infància i recuperar la il·lusió.

\begin{abstract}
AV: Al passat 2018, Regne Unit va fer públic un informe on es mostrava la importància de les arts en les persones, repercutint tant en l'economia com en la qualitat de vida. Cóm veu la situació del nostre país respecte a l'educació artística?
\end{abstract}

EA: Penso que queda un camí llarg, encara no es veu la música com el que és en realitat, ni la importància que té a nivell cerebral i emocional. Necessitem que la música estigui present a molts àmbits, però sobretot a l'escola com una assignatura imprescindible en l'educació global.
Però s'ha de ser optimista: "en el camí de la fe neix la força".

AV: Si poguera escollir tres competències per a transmetre als futurs mestres música(en qualsevol àmbit educatiu, quines escolliria?

EA: $M^{\prime}$ agradaria que els mestres de música fossin capaços de transmetre afecte, alegria i sensibilitat musical.

AV: Moltes gràcies per compartir els seus coneixements amb els lectores i lectores d'ARTSEDUCA

EA: Moltes gràcies a vosaltres per poder posar un gra de sorra en aquesta revista tant interessant! 


\section{Eulàlia Abad}

Pedagoga i cantant, ha rebut diversos cursos de formació musical solfeig i 3 anys de piano.

Formació pedagogia Willems, musicoteràpia a la Universitat de Vitòria amb Patxi del Campo, expressió corporal i dansa lliure entre d'altres. Ha participat durant anys en anuncis publicitaris per TV i ràdio, com a cantant solista en anuncis coneguts com Martini, Blevit, Castellblanch, la Once, Mc. Donalds, entre molts d'altres. També com a cantant solista acompanyada per músics com Conrad Setò o Toni Xuclà. en diferents concerts i espectacles. Ha compaginat la pedagogia treballant en diferents escoles bressol i de música de Barcelona, amb nens fins a 5 anys, utilitzant mètodes prestigiosos como els de Martenot i Willems. Durant els últims 20 anys s'ha dedicat a la recerca, desenvolupant el seu propi mèłode d'educació musical: Música per Créixer.

Música per Créixer, especial per nens de 0 a 3 i complementari d'altres mètodes de 3 a 5 anys He donat formació d'aquesta metodologia en diverses escoles, centres i col-lectius de Catalunya i València, i al Conservatori i escola de música El Musical de Bellaterra durant 15 anys, tenint diferents tipus d'un nombrós alumnat, com llevadores, mestres, musicoterapeutes, músics, cantants, educadors/es en lleure...

He donat cursos del mètode a la federació de músics de Valencia FSMCV. En I' any 2015 va presentar un projecte especial de Música i Valors per les escoles bressol per cultivar els valors a través de la música. Ha fet treballs i estudis de recerca de relaxació amb la musicoterapeuta Catherine Clancy i Gemma Baños, la importància de relaxar els nens de 2 anys amb el so de les campanes publicats a la revista $n^{\circ} 81$ Música y educació en l'any 2010, i en la revista digital Arts Educa Música, i relaxació en nens de 2 anys una experiència amb campanes i bols tibetans. Ha impartit tallers del mètode per educadors/es als departaments d'infantil, de magisteri de la Universitat de Barcelona, dirigits pel Doctor Josep Gustems, també seminaris a I' escola de musica Joan LLongueres. Actualment treballa al Conservatori El Musical de Bellaterra amb seminaris i cursos per mestres, reconeguts per la Generalitat de Catalunya, i colllabora permanentment en la elaboració i composició de material didàctic, cançons i contes musicals de valors. Fa dos anys col·labora al Master de Músicoteràpia Transcultural de la Fundació Universitat de Girona en I' assignatura Despertant la oïda, especial per nenes i nens prematurs. Recentment a l' any 2018 ha creat l'Associació Art Per Créixer, associació sense ànim de lucre per difondre l'art i els valors, amb la mestre de música Mireia Calduch, especialista de Música per Créixer i directora de l'escola de música Si Fa sol Musical de Santa María de Cervelló. 